\title{
Functional SNPs in the lymphotoxin- $\alpha$ gene that are associated with susceptibility to myocardial infarction
}

K Ozaki, Y Ohnishi, A lida, A Sekine, R Yamada, T Tsunoda, H Sato, H Sato, M Hori, Y Nakamura \& T Tanaka

Nat. Genet. 32, 650-654 (2002).

Published online 11 November 2002; doi:10.1038/ng1047

A typographical error in the third sentence of the abstract resulted in the $P$ value for the association being incorrectly reported as $P=0.00000033$. The correct value is, in fact, $P=0.0000033$.

corrigendum

Apc modulates embryonic stem-cell differentiation by controlling the dosage of $\beta$-catenin signaling

M F Kielman, M Rindapää, C Gaspar, N van Poppel, C Breukel, S van Leeuwen, M M Taketo, S Roberts, R Smits \& R Fodde

Nat. Genet. 32, 594-605 (2002).

Published online 11 November 2002; doi:10.1038/ng1045

The name of the second author was misspelled. The correct spelling is Maaret Ridanpää. 